\title{
PROMOTING CHIARO HOTEL USING A WEBSITE
}

\author{
Ivana Kurniawati, Jusuf Imam Ibrahim
}

English Department, Faculty of Letters, Petra Christian University, Siwalankerto 121-131, Surabaya 60236, East Java, Indonesia.

E-mail: kurniawati.ivana@gmail.com; jusufib@petra.ac.id

\begin{abstract}
Chiaro Hotel is a one-star hotel in Sidoarjo that is located at a strategic location. It is clean and comfortable family hotel. The problem of Chiaro Hotel is lack of promotion. Even though Chiaro Hotel has had some promotional tools, such as short promotional video, marketing booklet, and flyer, those promotional tools do not give good impact for the hotel because they do not show the uniqueness of Chiaro Hotel. Therefore, I make a website to solve Chiaro Hotel's problem. This website can reach people in many places. Also, this website can help Chiaro Hotel to show the uniqueness that the hotel has. For my project, the website is mostly in English. The features in this website are "Home", "About Us", "Room", "Facilities", "Latest News", "Contact Us", and "Booking Feature". The benefits that Chiaro Hotel can get from this website are to be well-known among its competitors and get more customers.
\end{abstract}

Key words: Promote, promotional tools, a website.

\section{INTRODUCTION}

I did my internship in Delta Sinar Mayang Hotel from March $3^{\text {rd }}$ to May $30^{\text {th }}, 2016$. Established in 2010, Delta Sinar Mayang Hotel is categorized as a three-star hotel in Central Sidoarjo. In this hotel, I worked in the marketing communication department and in the front office department.

At first, I wanted to do my project in this hotel. Unfortunately, at that time, Delta Sinar Mayang Hotel was under renovation. The management did not give me guarantee when I could start doing my project while I needed to get the place to do a project as soon as possible. That is why, I tried to find a new place to make a project. Finally, after coming to some hotels, Chiaro Hotel contacted and asked me to come there. Then, I met the owner and explained my plan to do a project. The owner felt interested in my offer about the project. Finally, she accepted my offer to do a project there.

The problem that I found in Chiaro Hotel is lack of promotion. The occupancy rate of Chiaro Hotel is still around 30-40\% per month. In other words, there are only 5-8 rooms booked every day. Actually, Chiaro Hotel has some promotional tools, such as a short promotional video, marketing booklet, and flyer. However, the promotional tools look like do not give big impact because they are not effective in promoting Chiaro Hotel. The promotional tools do not show the uniqueness of Chiaro Hotel that can attract people to come to the hotel.

The purpose of this Business Communication Final Project (BCFP) is to promote Chiaro Hotel. First, through the website, I expect the potential customers can know about Chiaro Hotel. So, people who have not known about Chiaro Hotel can know about the hotel. Second, this website can tell people about the uniqueness that Chiaro Hotel has. If Chiaro Hotel can show the uniqueness that it has, it can attract many people to come to the hotel. As for me, by working on this project, I expect to get a new experience. This experience will be very useful for me in the future. Second, I expect to apply my knowledge that I have got from EBC courses.

There are two benefits that the hotel can get from this Business Communication Product (BCP). First, this website can help Chiaro Hotel to be more well-known among its competitors. Through this website, people can easily know about Chiaro Hotel. Second, the website can help Chiaro Hotel to get more customers. After people know about Chiaro Hotel, they can be interested in coming to Chiaro Hotel.

\section{PRINCIPLES FOR DESIGNING NEW PRODUCT}

In designing this website, I use some theories from books and online sources. First of all, according to Oxford Dictionary of Business English for Learners of English (1993), promotion is "an advertising or other activity intended to increase the sales of a product or an advertising or 
publicity campaign for a particular product". Whereas according to businessdictionary.com (n.d), promotion is "the advancement of a product, idea, or point of view through publicity and/or advertising". Actually, there are many ways to do promotion. In order to solve Chiaro Hotel's problem, I chose to make a website. According to Bell (2011), a website is "a collection of web pages (called a web server) and accessed by outside computers."

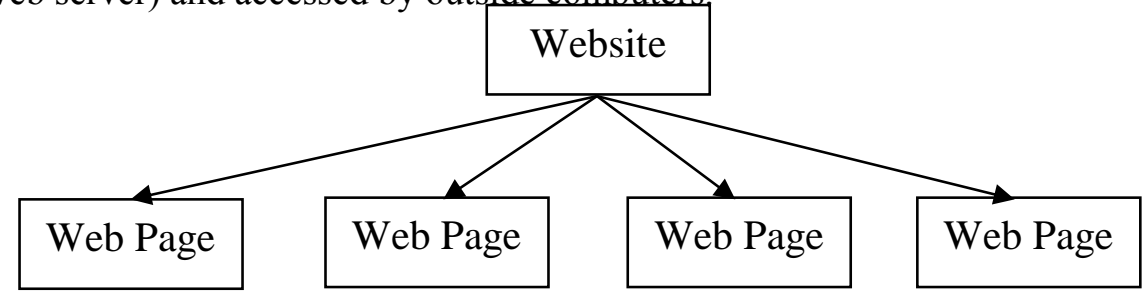

Moreover, Bell (2011) also explains there are 5 steps to create a website.

Website Creation Process

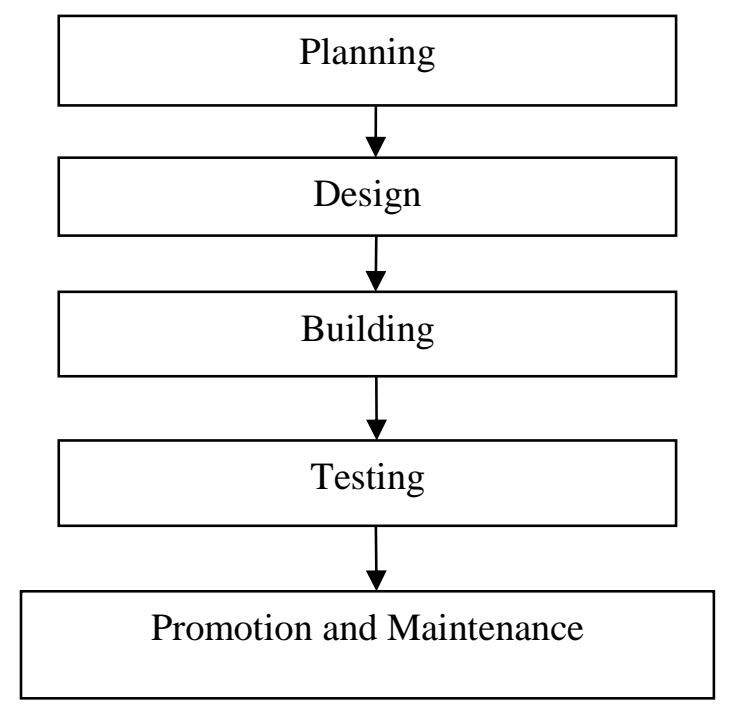

1. Planning

In this step, the company needs to prepare some steps to finish a project in order to make them easy to do the next steps.

2. Design

This step includes the way the pages are arranged, the button to make people easy access the website, and technical things like application technology that is used.

3. Building

It is the process of making pages, editing designs, creating links, arranging multimedia, adding scripts, etc. This step also contains web page creation tools, graphics tools, etc.

4. Testing

This step is done in order to make sure that everything on the website works well. For example, check the navigation (moving from every page in the website), designs, and content (to test that no information is missing).

5. Promotion and Maintenance

In this step, the company has to promote the website to other people and make sure it comes out on search engines. The company also has to maintain and update the website so that people still want to check it.

Next, he also mentions there are some types of website.

1) Business

This type of website is made to get income, new buyers, and working business model.

2) Personal

This type of website is created for personal interest where people can tell about their feeling, stories, and idea.

3) Social 
Social website is used to help the social interactions.

4) Informational

It is used to share either new information or knowledge.

The website for Chiaro Hotel is categorized as business website because it is used to promote

Chiaro Hotel. Through this website people can know about Chiaro Hotel. As a result, it can help Chiaro Hotel to increase the occupancy rate and the profit.

Furthermore, he stated some parts of the website.

$>$ Home Page

Home Page is the first page after the website is open. This page can make the first impression of the company. Therefore, the company should pay attention about it.

$>$ Content Pages

This page contains the explanation about the products and the pictures that the company has.

$>$ About Me Page

In here, the company should explain about themselves and the reason they create the website.

$>$ Frequently Asked Questions (FAQ)

This page consists of the questions and answer about the products or services that people may ask.

$>$ Contact Information

In this page, people can write their comments and questions about the company. It may contain their name, address, phone number, and email address.

In my project, I use all of them except Frequently Asked Questions (FAQ) feature because it is not relevant for Chiaro Hotel. Since Chiaro Hotel is a one-star hotel, it does not have many facilities compared to three-star, four-star, or five-star hotels. So, there will be no many questions from the guests.

It is possible there are some advantages in using website rather than marketing booklet.

1. A website can reach a wider market

According to javawebmaster.com (n.d), "in Indonesia, there are around 50 million people using internet" It means that it is a good opportunity for Chiaro Hotel to promote the hotel using website because people can know about the hotel. Also, since a website can be accessed globally, people from other cities, provinces, even countries can open the website. So, Chiaro Hotel's staff do not need to go to other cities, provinces, and countries to promote the hotel. In contrast, if Chiaro Hotel uses marketing booklet, they need to distribute marketing booklet directly to each person. It means that when the staff do not give the marketing booklet to people, people will not know about Chiaro Hotel.

2. A website can be updated anytime

If there is new information, Chiaro Hotel can write it in the website immediately. After they update the new information in the website, people can directly read that information. So, people will not miss any information about Chiaro Hotel. In updating the information in the website, Chiaro Hotel does not need to pay. Because it is their website, they can update it for free. Unlike the website, if Chiaro Hotel wants to update the information in the marketing booklet, they have to spend some money. Then, the old marketing booklet cannot be used again because the information is not complete. If Chiaro Hotel has the new marketing booklet, the staff have to distribute the new marketing booklet to people. If people do not get the new marketing booklet, they will not know about the new information in Chiaro Hotel.

In addition, the website that I make for Chiaro Hotel is mostly in English. It is important for a hotel to use English. As we know, the guests who may come to the hotel are local people and the foreigners. That is why, the hotel should consider with the language that they use. The hotel should write the information in English so that the foreigners can understand about the information in the website.

According to knowspeakenglish.com (n.d), "being able to speak English will demonstrate a level of intelligence to others." Usually, people have different perception to the one using English. Those who are using English can raise their status in society because people think they are professional. 
Smith (1983) said that English becomes an international language because of two reasons which are the impact of native English speaking countries and the reality that the world communication comes from people who can speak English.

According to Crystal (2003), "a global language is a language that gets a global status when used and recognized in every country". It can be used to communicate in some areas, such as in the government, the law courts, the media, and the educational system. It is also important in a country's foreign-language teaching although that language does not have legitimate status. Nowadays, English is the language most broadly used in over 100 countries such as China, Russia, Germany, Spain, Egypt, and Brazil. Other reasons why English becomes a global language are the extension the power of British in the end of the nineteenth century and the rise of the United States as the leading economic power of the twentieth century.

The colour that is used in the website is red and white colours. According to Dameria (2007) red colour is an eye-catching colour because this colour has hot energy. That is why, this colour has a power to make people pay attention with the product. Then, white colour shows the value of cleanliness in the product. Also, by using white as the background, red colour can be more emphasized.

\section{PRODUCTS AND RATIONALE}

The product is "Promoting Chiaro Hotel Using A Website". In this website, there are "Home", "About Us", "Room" (Superior Room and Deluxe Room), "Facilities" (Meeting Room, Mini-café, and Boutique), "Latest News", "Contact Us", and "Booking Feature".

This website is made for the potential customers of Chiaro Hotel. The first customer of Chiaro Hotel is the couples who will get married. Chiaro Hotel is near Rohmmatul Umah, a place for wedding reception. If they plan to hold the wedding reception on that building, they will try to find a hotel which is near that place. By using the website, that couples can know about Chiaro Hotel. If they know about it, they will choose to stay at Chiaro Hotel because the location of the hotel is near that building.

The second customer of Chiaro Hotel is the preachers. The location of Chiaro Hotel is also near some churches, such as Gereja Katolik Santa Maria Annutiata, Gereja Kristen Indonesia (GKI), and GPIB Bethesda. Sometimes, these churches invite some preachers to preach in their churches. If Chiaro Hotel has a website, the preachers can know about Chiaro Hotel. They can ask the church to let them stay at Chiaro Hotel because the location of Chiaro Hotel is close to the church.

The third customer of Chiaro Hotel is the companies. Sometimes, the companies ask their managers to come to other places in order to meet with the clients or do company's task in that place. If they need a hotel in Sidoarjo, they can find Chiaro Hotel from its website.

The fourth customer of Chiaro Hotel is the relatives of the families who live in Sidoarjo. Chiaro Hotel is also close to some residential areas, such as Bluru Permai and Bumi Citra Fajar. If the relatives will go to Sidoarjo, the family can recommend Chiaro Hotel to them because it is near their residential areas. The family can ask their relatives to open Chiaro Hotel's website in order to get the information about the hotel.

The fifth potential customer of Chiaro Hotel is people from outside Sidoarjo. If they do not have a friend or relative in Sidoarjo, the only way that they can do to find the hotel is by searching it on the internet. Since Chiaro Hotel has a website, they can easily find and get the information about Chiaro Hotel.

There are two purposes of this website for Chiaro Hotel. First, this website can be a way for Chiaro Hotel to reach a wider market. Since people have a high dependency with technology, especially internet, it is a great opportunity for Chiaro Hotel to have a website. People from everywhere can open the website. Second, by having a website, Chiaro Hotel can show the uniqueness that the hotel has. Chiaro Hotel can use the website to tell people about the good things which other hotels do not have. By doing this, it can make people curious about the hotel. As a result, they will come to Chiaro Hotel.

As I have explained above, there are 7 features in this website. The first feature is "Home". In this feature, I put 3 motion pictures which are the front view of Chiaro Hotel, mini-café, and room. Next, "About Us" feature contains the short explanation of Chiaro Hotel. In here, I explain about the uniqueness of Chiaro Hotel. I also put the short promotional video that Chiaro Hotel has had so that 
people can see Chiaro Hotel visually. Then, in "Room" feature, I give 2 options which are Superior Room and Deluxe Room. In every room, I put 2 motion pictures which are the picture of room and the bathroom and mention about all facilities. In addition, "Facilities" feature consists of Meeting Room, Mini-Café, and Boutique. In Meeting Room, I put a picture of meeting room and write the explanation about the facilities and 3 styles of meeting room. In Mini-Café, I show the picture of the employee who is making a cup of coffee and write the explanation that the mini-café sells cakes and Indonesian food. In Boutique, I put the picture of the Islamic clothing for women in order to emphasize the type of clothes that this boutique sells. Another feature is "Latest News". The function of this feature is to tell people about the guests who have stayed in Chiaro Hotel and the new information of Chiaro Hotel. However, when I made this website, there was no information in this feature. The owner just asked me to prepare this feature. Furthermore, "Contact Us" feature consists of the information about Chiaro Hotel, such as address, telephone number, e-mail, the location of map, and social media of Chiaro Hotel. The last feature is "Booking Feature". In this feature, I write an announcement which tells people that Chiaro Hotel only accommodates married couples with proven legal identification documents. Since it is the value that Chiaro Hotel holds, it is important for people to know about that information. Also, there is some requirements that people need to fulfill in order to book room in this hotel.

In this paragraph, I explain the reason about the order of the features in this website. First of all, since "Home" is the place where people can get the first impression of Chiaro Hotel, people can know about the good things in Chiaro Hotel through 3 motion pictures. If people are impressed with those motion pictures, they will be more likely to go to the next feature. Then, because there is some information and short promotional video in "About Us" feature, people can know about what Chiaro Hotel is. If they are interested, they can go to see rooms and facilities in the hotel. Next, I put "Room" feature because I want to show the pictures of room and bathroom in Superior Room and Deluxe Room and tell the facilities inside the room. Moreover, I put "Facilities" feature because I want to tell people that Chiaro hotel also has Meeting Room, Mini-café, and Boutique. Next, I put "Latest News" feature because I want to let people know about the guests who have stayed in Chiaro Hotel and the new information of Chiaro Hotel. Then, if people want to get further information about Chiaro Hotel, they can contact the hotel from the information in "Contact Us". Lastly, I put "Booking Feature" inside all features in order to make people easy to book room in Chiaro Hotel.

Lastly, I explain about theme, language, type of font, and colour that used in this website. The theme of this website is simple in order to make people easy to read the information in the website.

Moreover, the explanations in all features in this website are in English except in Latest News which are in Indonesian and English. The first reason why almost all of information in this website is in English because people think the company that uses English is professional. So, if Chiaro Hotel uses English in its website. It will be good for the image of Chiaro Hotel. Not only that, up to now there is no hotel in Sidoarjo which uses English in their website. Chiaro Hotel can be the first hotel in Sidoarjo that uses English in the website. In addition, the guests who come to the hotel can be local people and the foreigners. That is why, the hotel has to pay attention to the language that they use. In order to make the foreigners understand about the information in the website, the hotel should write it in English. Also, English is an international language. Since the website is in English, people from other countries can also read the information. Furthermore, the words that I use in the explanations are easy to be understood. If people do not understand about the information in the website, they can watch the summary about Chiaro Hotel from the short promotional video in "About Us". This short promotional video is in Indonesian, so it will be easy for people to understand about the information. On the other hand, "Latest News" uses 2 languages because the information about Latest News is just in this feature. By using 2 languages people can read the information in Indonesian if they do not understand about the explanation in English.

There are 2 types of fonts that I use in this website. First, I use Century Gothic for the contents. Since Century Gothic has the same thickness on the width and height, people will not be confused when they read the information. Also, Century Gothic is used almost in all website and browsers. Then, I use Yesteryear for the headings. It is a flat nib font style. I use two types of fonts in order to differentiate which one the heading and the content. 
I use red and white colours in Chiaro Hotel's website. Red colour is an eye-catching colour because it has hot energy. I want that colour to make people pay attention and read the information in the website. Moreover, white colour symbolizes the cleanliness. It is one of the uniqueness that Chiaro Hotel has. In addition, white colour can emphasize red colour in this website.

\section{CONCLUSION AND SUGGESTIONS}

In conclusion, I make a website for Chiaro Hotel. Chiaro Hotel is a clean and comfortable family hotel that provides modern furniture to serve the customers. The problem that I found in Chiaro Hotel is lack of promotion. The occupancy rate of Chiaro Hotel in every month is still low which is $30-40 \%$. Even though Chiaro Hotel has had some promotional tools, Chiaro Hotel does not get good impact from the promotional tools. It is because the promotional tools do not show the uniqueness that Chiaro Hotel has. That is why, I choose to make a website for Chiaro Hotel in order to solve this problem. This website can be used to reach people in many places and show the uniqueness that Chiaro Hotel has. The website that I make for Chiaro Hotel is mostly in English. Since some people assume English is professional, they will think Chiaro Hotel is a good hotel. Also, Chiaro Hotel can be the first hotel in Sidoarjo that uses English in the website. The features in the website are "Home", "About Us", "Room", "Facilities", "Latest News", "Contact Us", and "Booking Feature". There are two benefits that Chiaro Hotel can receive from the website. Chiaro Hotel can be well-known among its competitors and get more customers. To make this website effective, there are several things that Chiaro Hotel needs to do. First, Chiaro Hotel has to update the website when there is new information. Second, Chiaro Hotel needs to write the link of the website in its social media. Finally, the employees of Chiaro Hotel have to tell people about the website. Then, I have some suggestions for the next EBC students who are going to work on BCFP. First, they should find the company which wants to accept their offer to do a project. Next, they have to get the complete information of the company. Moreover, they need to manage their time effectively, so they can finish it on time. Also, they should to consider about the best promotional tool that can solve the company's problem. In addition, they need to consult about the content that they have made with the company. Lastly, they have to be convincing in explaining the company's proposal and the content of their project in order to make the company accepts their offer.

\section{REFERENCES}

Apa Manfaat Dan Keuntungan Membuat Website?. (n.d). Retrieved November 9, 2016 from http://javawebmaster.com/apa-manfaat-dan-keuntungan-membuat-website/

Bell, M. (2011). Build a Website for Free. Indiana: Pearson Education.

Crystal, D. (2003). English as a Global Language. Cambridge: Cambridge University Press.

Dameria, A. (2007). Color Basic Panduan Dasar Warna untuk Desainer Industri Grafika. Jakarta: Link \& Match Graphic.

Promotion. (1993). In Oxford Dictionary of Business English for Learners of English. Oxford: Oxford University Press.

Promotion. (n.d). Retrieved November 9, 2016 from http://www.businessdictionary.com/definition/promotion.html

Smith, L. E. 1983. Readings in English as an International Language. Oxford:Pergamon Press Ltd. Why it is so important to be able to speak English?. (n.d). Retrieved November 9, 2016 from http://www.knowspeakenglish.com/articles/why-it-is-so-important-to-be-able-to-speakenglish/ 